\begin{tabular}{|l|l|l||}
\hline \multicolumn{2}{|c|}{ PublisherInfo } \\
\hline \hline PublisherName & $:$ & BioMed Central \\
\hline \hline PublisherLocation & $:$ & London \\
\hline \hline PublisherImprintName & $:$ & BioMed Central \\
\hline \hline
\end{tabular}

\title{
UK probes scientific publications
}

\begin{tabular}{|l|l|l||}
\hline \multicolumn{2}{|c|}{ ArticleInfo } \\
\hline \hline ArticleID & $:$ & 4895 \\
\hline \hline ArticleDOI & $:$ & $10.1186 /$ gb-spotlight-20031212-01 \\
\hline \hline ArticleCitationID & $:$ & spotlight-20031212-01 \\
\hline \hline ArticleSequenceNumber & $:$ & 247 \\
\hline \hline ArticleCategory & $:$ & Research news \\
\hline \hline ArticleFirstPage & $:$ & 1 \\
\hline \hline ArticleLastPage & $:$ & 3 \\
\hline \hline & & RegistrationDate : 2003-12-12 \\
ArticleHistory & $:$ & OnlineDate \\
\hline \hline ArticleCopyright & $:$ & BioMed Central Ltd2003-12 \\
\hline \hline ArticleGrants & $:$ & \\
\hline \hline ArticleContext & $:$ & 130594411 \\
\hline \hline
\end{tabular}




\section{Pat Hagan}

Email: pat.hagan@btconnect.com

Britain's House of Commons Science and Technology Committee is to conduct an inquiry into the publication of scientific research, amid continued fears that the current system denies many researchers proper access to information.

The committee, made up of members of parliament (MPs) from across the political divide, will focus on the cost of receiving scientific journals and their availability to researchers, teachers, and students who need them for their work.

In a statement, the committee said the inquiry, which will run for several months, will also investigate what impact electronic publishing is having on "the integrity of journals and the scientific process."

Labour MP Ian Gibson, who chairs the committee, told us he hopes the outcome will be "an informed system" of publishing that is cheap and effective.

"If research is funded by public money, then it should be available to the public for free," he said.

The inquiry reflects growing concern that the current model of commercial publishing of print journals means many university scientists and students cannot afford to access key publications.

The committee also plans to look at so-called 'big deal' schemes, in which libraries can only receive the journals they want if they agree to buy a whole package of others from the same publisher.

It also wants to find out whether Legal Deposit Libraries - which have a statutory obligation to store copies of every scientific publication - are making electronically published research available to the scientific community and what action government, academic institutions, and publishers should be taking to promote a competitive market in scientific publications.

A key part of the inquiry will also focus on the trend toward more open-access journals and whether the government should be supporting such a shift.

Interested parties have until February 12, 2004, to submit written evidence. After that, the committee will begin taking oral evidence before compiling a final report.

Gibson added: "Scientific journals need to maintain their credibility and integrity as they move into the age of e-publication. The committee will have some very tough questions for publishers, libraries, and government on these issues."

Bob Ward, spokesman for the Royal Society, confirmed it would be submitting evidence to the inquiry.

He told us: "The society, as the founder of scientific publishing, supports any moves to improve the dissemination of high quality information." 
Ward also said the society recognizes that commercial publishers make "excessive profits" within this field. "But open access raises a number of issues. Firstly, the current model is that the costs associated with taking work from researchers and putting it into a format appropriate for dissemination is met through subscriptions," he added. "Open access shifts the cost of that on to the provider, and that raises questions over the ability of individual academics to bear the cost."

Jan Velterop, publisher at BioMed Central said it too would be submitting evidence. But he stressed that as one of the pioneers of open-access publishing, it would now prefer to take a back seat and let the wider debate on the future of scientific publishing take its course.

\section{References}

1. House of Commons Science and Technology Committee, [http://www.parliament.uk/]

2. Gavaghan H: Cut and thrust or parliamentary life February 18, The Scientist, 2003., [http://www.thescientist.com/news/20030218/06/]

3. Legal Deposit in the British Library, [http://www.bl.uk/about/policies/legaldeposit.html]

4. Royal Society, [http://www.royalsoc.ac.uk/] 